\section{Coir as an Alternative to Peat in Media for Tomato Transplant Production}

\author{
M. Arenas ${ }^{1}$ and C.S. Vavrina \\ University of Florida, Southwest Florida Research and Education Center, \\ 2686 State Road 29 North, Immokalee, FL 34142
}

J.A. Cornell

University of Florida, Department of Statistics, 508 Mc Carty Hall, Gainesville, FL 32611

\section{E.A. Hanlon}

University of Florida, Southwest Florida Research and Education Center, 2686 State Road 29 North, Immokalee, FL 34142

\section{G.J. Hochmuth}

University of Florida, North Florida Research and Education Center, 30 Research Road, Quincy, FL 32351-5684

Additional index words. Lycopersicum esculentum, Cocus nucifera, coconut pith, vegetable transplants, seedlings

Abstract. Sixteen media prepared from peat, coir, vermiculite, or perlite were used to determine the optimum growing media for tomato (Lycopersicum esculentum Mill.) transplants. Medium composition did not affect tomato seed emergence, although seedling emergence was higher in winter $(\mathbf{9 0} \%)$ than summer $(\mathbf{8 5} \%)$. Greatest transplant root dry weight, stem diameter, and leaf area were achieved in $50 \%$ to $75 \%$ peat $+25 \%$ to $50 \%$ vermiculite in summer. In winter, greatest transplant root dry weight, stem diameter, and leaf area were achieved in eight media: $100 \%$ peat, $75 \%$ peat $+25 \%$ vermiculite, $75 \%$ peat $+\mathbf{2 5} \%$ perlite, $\mathbf{5 0} \%$ peat $+\mathbf{5 0} \%$ vermiculite, $\mathbf{5 0} \%$ peat $+\mathbf{5 0} \%$ perlite, $25 \%$ peat $+\mathbf{5 0} \%$ coir $+25 \%$ vermiculite, $50 \%$ peat $+25 \%$ coir $+25 \%$ vermiculite, and $25 \%$ peat $+25 \%$ coir $+25 \%$ vermiculite $+\mathbf{2 5} \%$ perlite. Transplants grown with $>\mathbf{5 0} \%$ coir exhibited reduced plant growth compared to peat-grown transplants, a response that may be associated with high $\mathbf{N}$ immobilization by microorganisms and high $\mathrm{C}: \mathrm{N}$ ratio. Despite transplant growth differences during the summer, fruit yields generally were unaffected by transplant media.

About 25 billion ornamental and vegetable transplant plugs were produced in the United States in 1996 (Styer and Koranski, 1997), and Florida vegetable plugs accounted for $5 \%$ (1.3 billion) of the total production (Arenas, 1999). Peat moss has long been the primary component of transplant and potting media for both vegetable and ornamental plants. The standard vegetable transplant medium in Florida is $70 \%$ peat and $30 \%$ (by volume) vermiculite in summer, and $60 \%$ peat and $40 \%$ (by volume) vermiculite in winter. Although use of peat is substantial, the use of an alternative organic material was deemed worthy of consideration according to a transplant grower survey (Arenas, 1999). Whereas peat costs have increased annually, the price received for vegetable transplants has changed little since 1995 (Zimet and Vavrina, 1995).

Coconut (Cocus nucifera L.) pith or coir, the mesocarp of the fruit, is a waste product of the coconut industry and has been proposed as

Received for publication 11 Jan. 2001. Accepted for publication 31 July 2001. Florida Agricultural Experiment Station Journal Series no. R-08264. The use of brand names does not constitute a recommendation by the Univ. of Florida to the exclusion of other products.

${ }^{1}$ Current address: Arenas Centre de Jardineria, Ribas 1, 08328 Alella Barcelona, Spain. a possible alternative to peat in growth media due to its suitable physical and chemical properties (Bragg et al., 1993; Savithri and Hameed, 1994). In addition, coir is similar to peat in price (The Scotts Company, Marysville, Ohio, personal communication). Coir has been tested as a horticultural medium for several ornamental and agronomic crops with acceptable results (Creswell, 1992; Evans and Stamps, 1996; Meerow, 1994; Pill and Ridley, 1998). However, little work has been done with coir as a medium component in vegetable transplant production.

The objective of this study was to assess coir and peat, alone and in combination with other ingredients such as vermiculite or perlite, as media for tomato transplant production and to determine commercial acceptability of transplants grown in these media through an evaluation by commercial transplant production managers.

\section{Materials and Methods}

Coir and peat physical and chemical properties. Coir from Sri Lanka and sphagnum peat from Canada particle size, bulk density (BD), particle density (PD), total pore space (TPS), water-holding capacity (WHC), and volume shrinkage (VS) were measured according to the methods of De Boodt and Verdonck (1972). Particle size distribution was calculated using Martinez's (1992) method. Chemical properties of coir and peat media were measured following methods proposed by the Univ. of Florida, Institute for Food and Agricultural Science, Soil Testing Laboratory (ESTL) and Analytical Research Laboratory (ARL) (Hanlon et al., 1996). Coir and peat C:N ratio and the nitrogen immobilization index $\left(\mathrm{NDI}_{75}\right)$ were measured using the methods of Handreck (1992). The $\mathrm{NDI}_{75}$ index measures soluble nitrogen utilization by medium microbes and estimates additional nitrogen demand necessary to support appropriate plant growth in such media (Bragg and Whiteley, 1995).

Growth media. Sixteen media were formulated using peat and coir as the organic components, and vermiculite and perlite as the inorganic components (Table 1). No preplant fertilization was included in the media. The Scotts Company supplied the coir and peat organic materials. Vermiculite (Fafard, Anderson, S.C.; US. grade \# 2; bulk density 0.14 $\mathrm{g} \cdot \mathrm{cm}^{-3}$ ) and perlite (Fafard; US grade \#3; bulk density $0.05 \mathrm{~g} \cdot \mathrm{cm}^{-3}$ ) were purchased locally.

Cultural practices. Four greenhouse trials were conducted in June 1997, Aug. 1997, Jan. 1998, and Feb. 1998. Individual 242-cell Styrofoam flats $\left(2.5 \times 2.5 \times 6.5 \mathrm{~cm} ; 24 \mathrm{~cm}^{3} /\right.$ inverted pyramid cell; Speedling, Sun City, Fla.) of the various media were sown (one seed/cell) with 'Agriset 761' tomato seeds (Petoseed Co., Saticoy, Calif.) Seedlings were grown in an open-sided greenhouse in Immokalee, Fla., in natural conditions. Flats of the 16 media were arranged in randomized complete blocks with four replications on rails within the greenhouse. A rotation of the trays within blocks was performed daily to avoid positional bias. All plants were grown for 6 weeks. Transplants were overhead-irrigated daily and fertigated twice weekly with $\mathrm{N}$ at 50 $\mathrm{mg} \cdot \mathrm{L}^{-1}$ from $20 \mathrm{~N}-8.6 \mathrm{P}-16.6 \mathrm{~K}$ fertilizer (Prolific, Riverside/Terra Corp, Sioux City, Iowa). Manzate 200 DF (zinc ion and manganese ethylene bisolithiocarbamate $75 \%$ ) and Kocide 100 (copper sulfate $98 \%$ ) were applied weekly to control fungi and bacteria. Dipel 2X (Bacillus thuringiensis var. kurstaki $6.4 \%$ ) was

Table 1. Components of the 16 transplant media evaluated.

\begin{tabular}{rccc}
\hline \hline Coir & Peat & Vermiculite & Perlite \\
\hline-------- & $(\%$ by volume $)$ & ------------ \\
100 & 0 & 0 & 0 \\
0 & 100 & 0 & 0 \\
50 & 50 & 0 & 0 \\
50 & 0 & 50 & 0 \\
50 & 0 & 0 & 50 \\
0 & 50 & 50 & 0 \\
0 & 50 & 0 & 50 \\
75 & 0 & 25 & 0 \\
75 & 0 & 0 & 25 \\
\hline 0 & $75^{z}$ & 25 & 0 \\
\hline 0 & 75 & 0 & 25 \\
50 & 25 & 25 & 0 \\
50 & 25 & 0 & 25 \\
25 & 50 & 25 & 0 \\
25 & 50 & 0 & 25 \\
25 & 25 & 25 & 25 \\
\hline
\end{tabular}

Industry standard: $75 \%$ peat $+25 \%$ vermiculite. 
sprayed as needed for larval Lepidoptera control. Six-week-old transplants from the Aug. 1997 experiment were planted in the field in an Immokalee fine sand (sandy, silicaceous, hyperthermic, Aenic Haplaquod). Generalized Florida transplant production techniques harden plants; therefore, no additional hardening techniques were employed.

Field-set transplants were arranged in randomized complete blocks with four replications. Each plot contained 14 plants at $45-\mathrm{cm}$ in-row and $1.8-\mathrm{m}$ between-row spacing. Field fertilization was determined by soil test $\mathrm{P}$ and Univ. of Florida Extension $\mathrm{N}$ and $\mathrm{K}$ recommendations (Hochmuth and Maynard, 1998.) A granular 5N-6.8P-6.6K fertilizer was broadcast at a rate of $\mathrm{N}$ at $39 \mathrm{~kg} \cdot \mathrm{ha}^{-1}$ prior to bedding. Soil was subsequently fumigated with methyl bromide ( $300 \mathrm{~kg} \cdot \mathrm{ha}^{-1}$ broadcast) while the 80 $\mathrm{cm}$-wide beds were being formed and covered with white-on-black plastic mulch $(0.003-\mathrm{mm}$.) Drip irrigation was employed using Netafilm SL-80 drip tape with an emitter spacing of $45.7 \mathrm{~cm}$ and a flow rate of $1.4 \mathrm{~L} \cdot \mathrm{h}^{-1}$. Fertigation began 2 weeks after transplanting with twiceweekly injections. In Fall 1997, N at 197 $\mathrm{kg} \cdot \mathrm{ha}^{-1}(8 \mathrm{~N}-0 \mathrm{P}-6.6 \mathrm{~K} ; 614 \mathrm{~L})$ was injected during the season.

Data collection. Total emergence (TE) and mean days to emergence (MDE) were recorded for each trial. MDE was quantified using the formula proposed by Gerson and Honma (1978). Plant growth measurements of the 6-week-old tomato transplants included shoot and root dry weight, leaf area, stem length, stem diameter (measured above cotyledons), and leaf chlorophyll concentration of second true leaf. Data were tabulated by evaluating five individual transplants per experimental unit. Leaf area was recorded using a LI3000A portable area meter (LI-COR, Lincoln, Nebr.); stem diameter was quantified by an ultra-call Mark III electronic caliper (Fred. V. Fowler Co., Newton, Mass.); and leaf chlorophyll concentration by a Spad-502 chlorophyll meter (Minolta Camera Co. Ltd., Osaka, Japan). Tomato fresh weight yield was recorded at each of three harvests (10-d intervals) by separating color and mature green fruit according to USDA (1998) size grades.

Florida transplant grower survey. Greenhouse managers from four vegetable transplant nurseries located in the Immokalee area of Florida (Barnett-Partin Plants Inc., Johnson Plants, LaBelle Plant World, and TransGrow Plant Co.) visually rated the plant growth of the 6-week-old transplants from the growth medium trial concluded in Feb. 1998. Transplant growth rating was based on a scale where: 1 = poor, 2 = fair, $3=$ acceptable, $4=$ good, and $5=$ excellent. General plant habit, color, stem diameter, root development, ease of removal from tray, and media loss as a result of removal were evaluated. Florida transplant growers generally base transplant growth on three major parameters: root development, stem diameter, and leaf area (Arenas, 1999).

Statistical analysis. Data were subjected to analysis of variance (ANOVA). Gupta's mean separation test was performed on each of the plant growth and yield parameters measured in order to group them best to worst (Gupta and Sobel, 1957). Gupta's test is preferred to least significant difference (LSD) or Duncan's procedure when, at a specific level of confidence, one wishes to say, "We feel X\% confident the best treatment is among those in this quality grouping." The other procedures-LSD and Duncan's - simply compare means on a pairwise basis.

\section{Results and Discussion}

Coir vs. peat physical and chemical properties. Coir and peat particle size distribution was predominantly within the range (0.25-2.5 $\mathrm{mm}$ ) suggested to be optimal for a growth medium (Abad et al., 1992): 89\% (by weight) for coir and $60 \%$ (by weight) for peat. Bragg et al. (1993), and Evans et al. (1996) reported similar particle size for coir between 0.5 and $2.0 \mathrm{~mm}$ in diameter.

Coir and peat had similar BD and PD, but coir had higher TPS, WHC, pH, EC, C:N, and $\mathrm{NDI}_{75}$ than peat (Table 2). The results presented in Table 2 were consistent with those cited by Martinez et al. (1997), Prasad (1997a), and Wever and Leeuwen (1994).

Coir was less acidic than peat and had higher EC. Both coir and peat exhibited similar organic matter $(>90 \%)$ and mineral content $(<10 \%)$ (data not shown) and were within an acceptable range cited by Abad et al. (1992).
Coir C: $\mathrm{N}$ ratio value was considerably greater than that of peat. Coir $\mathrm{C}: \mathrm{N}$ ratio reported in the literature ranged from 60:1 (Savithri and Hameed, 1994) to 220:1 (Lemaire, 1997), depending on the coir source.

The coir $\mathrm{N}$ drawdown index $\left(\mathrm{NDI}_{75}\right)$, a measure of soluble nitrogen immobilization by microorganisms, was 0.79 , while that of peat was 1.07. These values are consistent with determinations by Creswell (1992), Handreck (1992), and Prasad (1997b). NDI values $<1$ indicate that microorganisms are consuming soluble nitrogen in the medium nutritional solution, and values $>1$ indicate no $\mathrm{N}$ immobilization. The $\mathrm{NDI}_{75}$ value generally is inversely related to the $\mathrm{C}: \mathrm{N}$ ratio.

Germination. Media composition did not affect TE (data not shown); however, MDE varied from 6.7 and $7.1 \mathrm{~d}$ between media. Differences in MDE between media were generally $<8 \mathrm{~h}$, indicating fair uniformity across all 16 media. These MDE values were within the recommended range (4-7 d) for tomato as suggested by Styer and Koranski (1997). Perlite media significantly delayed germination, resulting in the highest MDE values. This delay could be related to the fact that peat, coir, and vermiculite all have higher water-holding capacities than perlite (Styer and Koranski, 1997), a key factor in optimizing germination (Cantliffe, 1998.)

Seeding date $\times$ media interaction effects

Table 2. Total pore space (TPS), bulk density (BD), particle density (PD), water-holding capacity (WHC), $\mathrm{pH}$, electrical conductivity $(\mathrm{EC})$, carbon to nitrogen ratio $(\mathrm{C}: \mathrm{N})$, and nitrogen drawdown index $\left(\mathrm{NDI}_{75}\right)$ of coir and peat.

\begin{tabular}{lcccccccc}
\hline & TPS & BD & PD & WHC & EC & & \\
& $(\%)$ & $\left(\mathrm{g} \cdot \mathrm{cm}^{-3}\right)$ & $\left(\mathrm{g} \cdot \mathrm{cm}^{-3}\right)$ & $(\%$ by wt $)$ & $\mathrm{pH}^{\mathrm{z}}$ & $\left(\mathrm{dS} \cdot \mathrm{m}^{-1}\right)$ & $\mathrm{C}: \mathrm{N}$ & $\mathrm{NDI}_{75}{ }^{\mathrm{y}}$ \\
\hline Coir & 94.64 & 0.06 & 1.54 & 763 & 5.36 & 0.75 & $117: 1$ & 0.79 \\
Peat & 93.54 & 0.07 & 1.51 & 695 & 4.16 & 0.18 & $46: 1$ & 1.07 \\
Significance & $*$ & NS & NS & $*$ & $*$ & $*$ & $*$ & $*$
\end{tabular}

${ }^{\mathrm{z}} \mathrm{pH}$ and EC were determined via saturated paste extract 1 part medium to 2 parts water.

${ }^{y} \mathrm{NDI}_{75}$ index has no units.

ss, *Nonsignificant or significant at $P \leq 0.05$.

Table 3. Transplant growers' evaluation of 6-week-old tomato transplants grown in media prepared from coir (C), peat (P), vermiculite (V), or perlite (Pr), Feb. 1998.

\begin{tabular}{|c|c|c|c|c|c|c|c|c|c|}
\hline & & & & \multicolumn{6}{|c|}{ Transplant growth rating ${ }^{2}$} \\
\hline \multicolumn{4}{|c|}{ Medium components } & \multirow{2}{*}{$\begin{array}{l}\text { Root } \\
\text { dev. }\end{array}$} & \multirow{2}{*}{$\begin{array}{l}\text { Stem } \\
\text { diam }\end{array}$} & \multirow{2}{*}{$\begin{array}{l}\text { Leaf } \\
\text { color }\end{array}$} & \multirow{2}{*}{$\begin{array}{c}\text { Ease of removal } \\
\text { from tray }\end{array}$} & \multirow{2}{*}{$\begin{array}{l}\text { Media } \\
\text { loss }\end{array}$} & \multirow{2}{*}{$\begin{array}{c}\text { General } \\
\text { appearance }\end{array}$} \\
\hline $\mathrm{C}$ & $\mathrm{P}$ & $\mathrm{V}$ & $\mathrm{Pr}$ & & & & & & \\
\hline 100 & 0 & 0 & 0 & 2.50 & $3.75^{*}$ & $4.25^{*}$ & 2.75 & 2.50 & $3.75^{*}$ \\
\hline 0 & 100 & 0 & 0 & $4.50^{*}$ & 4.00* & $4.00^{*}$ & $4.75^{*}$ & $4.75^{*}$ & $4.00^{*}$ \\
\hline 50 & 50 & 0 & 0 & $3.25^{*}$ & $3.00^{*}$ & $3.25^{*}$ & 3.25 & $3.75^{*}$ & $3.00^{*}$ \\
\hline 50 & 0 & 50 & 0 & 1.75 & 2.50 & $3.50^{*}$ & 2.75 & 2.50 & 2.50 \\
\hline 50 & 0 & 0 & 50 & 1.00 & 1.00 & 1.00 & 1.00 & 1.00 & 1.00 \\
\hline 0 & 50 & 50 & 0 & 2.75 & $3.25^{*}$ & $4.00^{*}$ & 2.75 & 2.50 & $3.50^{*}$ \\
\hline 0 & 50 & 0 & 50 & $3.25^{*}$ & 2.75 & $3.25^{*}$ & $3.50^{*}$ & $3.50^{*}$ & $2.75^{*}$ \\
\hline 75 & 0 & 25 & 0 & 1.50 & 2.00 & 3.00 & 2.00 & 2.50 & 2.50 \\
\hline 75 & 0 & 0 & 25 & 1.75 & 2.00 & 2.75 & 1.50 & 1.50 & 2.50 \\
\hline 0 & $75^{x}$ & 25 & 0 & $3.50^{*}$ & $3.00^{*}$ & $3.50^{*}$ & $3.50^{*}$ & $3.75^{*}$ & $3.50^{*}$ \\
\hline 0 & 75 & 0 & 25 & $3.50^{*}$ & 2.75 & $3.25^{*}$ & 3.25 & $3.75^{\circ}$ & $3.00^{*}$ \\
\hline 50 & 25 & 25 & 0 & 2.75 & 2.50 & 3.00 & 2.75 & $3.25^{*}$ & 2.50 \\
\hline 50 & 25 & 0 & 25 & 2.75 & 2.25 & $3.25^{*}$ & 3.00 & $3.25^{*}$ & $2.75^{*}$ \\
\hline 25 & 50 & 25 & 0 & $3.25^{*}$ & 2.75 & $3.50^{*}$ & $3.50^{*}$ & 3.00 & $3.00^{*}$ \\
\hline 25 & 50 & 0 & 25 & 2.75 & 2.50 & 3.00 & 2.75 & 2.50 & 2.50 \\
\hline 25 & 25 & 25 & 25 & $3.75^{*}$ & $3.25^{*}$ & $3.75^{*}$ & $3.75^{*}$ & $3.50^{*}$ & $3.50^{*}$ \\
\hline \multicolumn{4}{|c|}{ Gupta's $(P \leq 0.05)$} & $*$ & $*$ & $*$ & $*$ & $*$ & $*$ \\
\hline
\end{tabular}

${ }^{\mathrm{z}}$ Grading scale: 1 = poor; 2 = fair; 3 = acceptable; 4 = good; $5=$ excellent

yoot development.

Industry standard: $75 \%$ peat $+25 \%$ vermiculite.

*Means are expected to be among the best $(P \leq 0.05)$ as determined by Gupta's test. 
were nonsignificant; however, the overall seeding date effect showed MDE was shorter in June (6.04) than in January (7.51) or February (7.09); by contrast, TE was higher in January and February (89\% and 90\%, respectively) than in June and August (86\% and $83 \%$, respectively). The combination of greater soil temperatures, higher irradiance levels, and increased irrigation frequencies during the summer trials was more conducive to rapid initial emergence (i.e., lower MDE). However, these same environmental stresses, especially temperatures $>30^{\circ} \mathrm{C}$, can reduce overall emergence (Vavrina, 1996). Optimal temperature for tomato seed germination is 21 to $24^{\circ} \mathrm{C}$ (Styer and Koranski, 1997).

Florida transplant grower survey. Visual ratings by Florida transplant growers (Table 3 ) indicated that transplants in all peat media and seven media containing coir were acceptable by industry standards (Arenas, 1999). Media containing $50 \%$ or $75 \%$ coir with perlite or vermiculite were rejected due to small stem diameters and root systems, variables deemed most important by Florida transplant growers (Arenas, 1999). High correlation coefficients were found between grower ratings and measured values for root system, stem diameter, and general plant habit $(r=0.85,0.79$, and 0.70 , respectively, $P<0.01)$.

Transplant growth and yield. Tomato transplants grown during the summer exhibited greater growth when grown in peat rather than coir (Table 4). Transplants grown in $100 \%$ peat, $75 \%$ peat $+25 \%$ vermiculite, or $50 \%$ peat $+50 \%$ vermiculite had greater root dry weight, stem diameter, leaf area, shoot dry weight, and stem length than transplants grown in other media. Leaf chlorophyll concentration was unaffected by growth media.

Based on root dry weight and stem diameter (two Florida transplant grower criteria), eight media generated larger transplants in Winter 1998: five media with peat as the sole organic component, and three media with peat and coir as the organic component (Table 5). Shoot dry weights were similar for 14 of the 16 media, but the higher leaf chlorophyll concentration of peat-grown plants was useful in assessing winter transplant quality.

Transplants grown in a high content of coir ( $\geq 50 \%$ coir) did not grow as vigorously as peat-grown transplants when fertilized twice weekly with $\mathrm{N}$ at $50 \mathrm{mg} \cdot \mathrm{L}^{-1}$ in both summer and winter. Additional trials designed to overcome coir $\mathrm{NDI}_{75}$ deficiencies (data not shown) indicated that $\mathrm{N}$ at 75 to $100 \mathrm{mg} \cdot \mathrm{L}^{-1}$ was sufficient to reduce visual differences between peat and coir transplants, but the grower panel assessment of transplant quality among the 16 media remained unchanged (Arenas, 1999).

Merrow (1994) also reported reduced plant growth in coir-based media compared to peatbased media (four coir/peat + one sand; by volume) for Ixora coccinea L. in Florida. Reduced plant growth was attributed to the soluble $\mathrm{N}$ immobilization by coir microorganisms, as suggested by our coir $0.79 \mathrm{NDI}_{75}$ value and those of other studies (Cresswell, 1992; Handreck, 1992; Prasad, 1997b). Pill and Ridley (1998) reported no plant growth differ-

Table 4. Growth of 6-week-old tomato transplants in media prepared from coir $(C)$, peat $(\mathrm{P})$, vermiculite $(\mathrm{V})$, or perlite (Pr), Summer 1997.

\begin{tabular}{|c|c|c|c|c|c|c|c|c|c|}
\hline & & & & \multicolumn{6}{|c|}{ Summer 1997} \\
\hline \multicolumn{4}{|c|}{ Media components $(\%)$} & $\begin{array}{l}\text { Root } \\
\text { dry wt }\end{array}$ & $\begin{array}{l}\text { Stem } \\
\text { diam }\end{array}$ & $\begin{array}{l}\text { Leaf } \\
\text { area }\end{array}$ & $\begin{array}{l}\text { Shoot } \\
\text { dry wt }\end{array}$ & $\begin{array}{c}\text { Stem } \\
\text { length }\end{array}$ & $\begin{array}{c}\text { Leaf } \\
\text { chlorophyll }\end{array}$ \\
\hline $\mathrm{C}$ & $\mathrm{P}$ & $\mathrm{V}$ & $\mathrm{Pr}$ & $(\mathrm{mg})$ & $(\mathrm{mm})$ & $\left(\mathrm{cm}^{2}\right)$ & $(\mathrm{mg})$ & $(\mathrm{cm})$ & concn \\
\hline$\overline{100}$ & 0 & 0 & 0 & 31 & 2.60 & 17.27 & 118 & 9.30 & 26.45 \\
\hline 0 & 100 & 0 & 0 & $48^{*}$ & $2.85^{*}$ & 16.69 & $174^{*}$ & $10.59^{*}$ & $29.17^{*}$ \\
\hline 50 & 50 & 0 & 0 & 32 & 2.58 & 16.42 & 107 & 8.71 & $27.77^{*}$ \\
\hline 50 & 0 & 50 & 0 & 32 & 2.64 & 15.00 & 117 & 9.14 & $29.23^{*}$ \\
\hline 50 & 0 & 0 & 50 & 30 & 2.61 & 14.84 & 109 & 9.19 & 28.01* \\
\hline 0 & 50 & 50 & 0 & $52 *$ & $2.95^{*}$ & 22.39* & $183^{*}$ & $11.91^{*}$ & $29.34^{*}$ \\
\hline 0 & 50 & 0 & 50 & 45 & 2.69 & 18.13 & 136 & 9.68 & $28.51^{*}$ \\
\hline 75 & 0 & 25 & 0 & 32 & 2.66 & 14.94 & 120 & 9.60 & 26.98 \\
\hline 75 & 0 & 0 & 25 & 33 & 2.67 & 15.08 & 121 & 9.04 & $27.68^{*}$ \\
\hline 0 & $75^{z}$ & 25 & 0 & $48^{*}$ & $2.95^{*}$ & $19.92^{*}$ & $175^{*}$ & $10.80^{*}$ & $28.56^{*}$ \\
\hline 0 & 75 & 0 & 25 & 45 & $2.82^{*}$ & $19.74^{*}$ & 152 & 10.21 & $29.22^{*}$ \\
\hline 50 & 25 & 25 & 0 & 30 & 2.56 & 13.22 & 106 & 8.84 & $26.96^{*}$ \\
\hline 50 & 25 & 0 & 25 & 31 & 2.56 & 13.66 & 104 & 8.87 & $27.55^{*}$ \\
\hline 25 & 50 & 25 & 0 & 36 & 2.69 & 15.18 & 120 & 9.34 & 28.94* \\
\hline 25 & 50 & 0 & 25 & 38 & 2.72 & 16.16 & 132 & 9.47 & $28.54^{*}$ \\
\hline 25 & 25 & 25 & 25 & 32 & 2.58 & 13.70 & 120 & 9.06 & $27.64^{*}$ \\
\hline
\end{tabular}

Industry standard: $75 \%$ peat $+25 \%$ vermiculite

"Means expected to be among the best $(P \leq 0.05)$ as determined by Gupta's test.

Table 5. Growth of 6-week-old tomato transplants in media prepared from coir $(\mathrm{C})$, peat $(\mathrm{P})$, vermiculite $(\mathrm{V})$, or perlite $(\mathrm{Pr})$, Winter 1998.

\begin{tabular}{|c|c|c|c|c|c|c|c|c|c|}
\hline & & & & \multicolumn{6}{|c|}{ Winter 1998} \\
\hline \multicolumn{4}{|c|}{ Media components (\%) } & $\begin{array}{l}\text { Root } \\
\text { dry wt }\end{array}$ & $\begin{array}{l}\text { Stem } \\
\text { diam }\end{array}$ & $\begin{array}{l}\text { Leaf } \\
\text { area }\end{array}$ & $\begin{array}{l}\text { Shoot } \\
\text { dry wt }\end{array}$ & $\begin{array}{c}\text { Stem } \\
\text { length }\end{array}$ & $\begin{array}{c}\text { Leaf } \\
\text { chlorophyll }\end{array}$ \\
\hline $\mathrm{C}$ & $\mathrm{P}$ & V & $\operatorname{Pr}$ & $(\mathrm{mg})$ & $(\mathrm{mm})$ & $\left(\mathrm{cm}^{2}\right)$ & $(\mathrm{mg})$ & $(\mathrm{cm})$ & concn \\
\hline 100 & 0 & 0 & 0 & 24 & $2.25^{*}$ & 15.22 & $\mathbf{8 3}^{*}$ & $9.60^{*}$ & 27.33 \\
\hline 0 & 100 & 0 & 0 & $30^{*}$ & $2.34^{*}$ & $18.69^{*}$ & $9^{*}$ & 9.91* & $30.35^{*}$ \\
\hline 50 & 50 & 0 & 0 & 24 & 2.15 & 14.50 & $8^{*}$ & 8.95 & 26.82 \\
\hline 50 & 0 & 50 & 0 & 20 & $2.21^{*}$ & 14.31 & 77 & $9.70^{*}$ & 27.73 \\
\hline 50 & 0 & 0 & 50 & 20 & 1.99 & 13.15 & $82^{*}$ & 8.58 & 27.41 \\
\hline 0 & 50 & 50 & 0 & $27^{*}$ & $2.35^{*}$ & $18.87^{*}$ & $95^{*}$ & $10.70^{*}$ & $29.42^{*}$ \\
\hline 0 & 50 & 0 & 50 & $28^{*}$ & $2.20^{*}$ & $16.71^{*}$ & $97^{*}$ & 9.35 & $29.04^{*}$ \\
\hline 75 & 0 & 25 & 0 & 22 & 2.13 & 13.49 & $87^{*}$ & 8.87 & 27.06 \\
\hline 75 & 0 & 0 & 25 & 22 & 2.17 & 13.68 & 80 & 8.84 & 27.54 \\
\hline 0 & $75^{2}$ & 25 & 0 & $29^{*}$ & $2.31^{*}$ & $18.31^{*}$ & $94^{*}$ & $\mathbf{9 . 9 3}^{*}$ & 30.88 \\
\hline 0 & 75 & 0 & 25 & $28^{*}$ & $2.27^{*}$ & $18.32^{*}$ & $85^{*}$ & 9.39 & $29.26^{*}$ \\
\hline 50 & 25 & 25 & 0 & $26^{*}$ & $2.28^{*}$ & $16.91^{*}$ & $81^{*}$ & $10.08^{*}$ & 26.83 \\
\hline 50 & 25 & 0 & 25 & 23 & 2.14 & 14.96 & $81^{*}$ & 8.97 & 27.05 \\
\hline 25 & 50 & 25 & 0 & $26^{*}$ & $2.25^{*}$ & $17.47^{*}$ & $86^{*}$ & $9.76^{*}$ & $29.45^{*}$ \\
\hline 25 & 50 & 0 & 25 & $25^{*}$ & 2.15 & 15.25 & 90* & 8.82 & 28.74 \\
\hline 25 & 25 & 25 & 25 & $26^{*}$ & $2.27^{*}$ & $16.25^{*}$ & $85^{*}$ & $9.65^{*}$ & 28.14 \\
\hline
\end{tabular}

Industry standard: $75 \%$ peat $+25 \%$ vermiculite.

*Means expected to be among the best $(P \leq 0.05)$ as determined by Gupta's test.

ences between 5-week-old transplants grown in coir media vs. peat media using weekly fertilizations with $\mathrm{N}$ at $350 \mathrm{mg} \cdot \mathrm{L}^{-1}$ or with Osmocote (10N-0.4P-14.9K) incorporated at $4 \mathrm{Kg} \cdot \mathrm{m}^{-3}$ medium. Vavrina et al. (1998) showed that increasing transplant fertilization in south Florida resulted in leggy transplants and reduced yield in fall-grown tomato; therefore, overcoming the $\mathrm{NDI}_{75}$ for coir-grown transplants might require increasing management inputs.

Despite obvious transplant growth differences among media, total fall tomato yields were generally unaffected by transplant media (Table 6). Tomato yields over three harvests ranged from 39.8 to $49.1 \mathrm{MT} \cdot \mathrm{ha}^{-1}$ and were similar to average yields of 36.0 to 40.0 $\mathrm{MT} \cdot \mathrm{ha}^{-1}$ in Florida (Hochmuth and Maynard, 1998). At first harvest, mature green fruit yield in both extra-large (XL; $P<0.05)$ and total fruit production $(P=0.065)$ were greatest for transplants grown in $50 \%$ coir $+50 \%$ vermicu- lite. Transplants grown in all media had similar yields to the transplants grown in the industry standard media ( $75 \%$ peat $+25 \%$ vermiculite), with the exception of the medium containing $25 \%$ each of coir, peat, vermiculite, and perlite. Coir transplants generated similar or greater tomato yields than peat transplants. These data suggest that visual estimates of transplant growth were not closely associated with subsequent fruit yield.

In summary, we were unable to determine an optimal medium formulation for tomato transplants due to seasonal variation in plant growth and incongruities between visual assessment of transplants and field yield. While peat + vermiculite media resulted in superior transplant growth in the summer, subsequent fall tomato yields were unaffected by transplant media. Tomato transplants grown in coir produced first harvest yields (extra large and total) that were comparable to, or higher than the industry standard $75 \%$ peat $+25 \%$ ver- 
Table 6. Red/breaker and mature green 'Agriset 671' tomato yield at first harvest and sum of three harvests from the 16-media study, Fall 1997.

\begin{tabular}{|c|c|c|c|c|c|c|c|c|c|}
\hline & & & & \multicolumn{5}{|c|}{ 1st Harvest $\left(\mathrm{T} \cdot \mathrm{ha}^{-1}\right)$} & \multirow{4}{*}{$\begin{array}{c}3 \text { Harvests } \\
\mathrm{T} \cdot \mathrm{ha}^{-1} \\
\text { Total }\end{array}$} \\
\hline & & & & \multicolumn{2}{|c|}{ Red/breaker } & \multicolumn{2}{|c|}{ Mature green } & \multirow{3}{*}{$\begin{array}{c}\text { Total } \\
\text { Red and } \\
\text { green) }\end{array}$} & \\
\hline \multicolumn{4}{|c|}{ Medium components (\%) } & Extra & & Extra & & & \\
\hline Coir & Peat & Vermiculite & Perlite & large & Total & large & Total & & \\
\hline 100 & 0 & 0 & 0 & 1.43 & 1.43 & $10.66^{*}$ & $10.96^{*}$ & 12.39 & 45.27 \\
\hline 0 & 100 & 0 & 0 & 2.35 & 2.48 & 8.50 & 8.97 & 11.45 & 45.30 \\
\hline 50 & 50 & 0 & 0 & 4.04 & 4.24 & 8.64 & 9.18 & 13.42 & 44.24 \\
\hline 50 & 0 & 50 & 0 & 0.48 & 0.92 & $14.95^{*}$ & $15.00^{*}$ & 16.30 & 49.05 \\
\hline 50 & 0 & 0 & 50 & 1.61 & 1.61 & 7.53 & 8.03 & 9.63 & 40.97 \\
\hline 0 & 50 & 50 & 0 & 2.91 & 2.94 & 9.12 & 9.68 & 12.63 & 41.91 \\
\hline 0 & 50 & 0 & 50 & 2.18 & 2.18 & $10.98^{*}$ & 11.82* & 13.99 & 47.56 \\
\hline 75 & 0 & 25 & 0 & 1.10 & 1.10 & 8.56 & 9.34 & 10.44 & 40.48 \\
\hline 75 & 0 & 0 & 25 & 0.92 & 0.92 & $10.29^{*}$ & $10.68^{*}$ & 11.59 & 43.92 \\
\hline 0 & $75^{2}$ & 25 & 0 & 0.93 & 0.93 & $12.12^{*}$ & $12.67^{*}$ & 13.59 & 46.12 \\
\hline 0 & 75 & 0 & 25 & 1.45 & 1.53 & 8.28 & 8.83 & 10.36 & 47.51 \\
\hline 50 & 25 & 25 & 0 & 2.10 & 2.14 & $10.18^{*}$ & $10.50^{*}$ & 12.64 & 42.44 \\
\hline 50 & 25 & 0 & 25 & 1.00 & 1.00 & 8.58 & 9.25 & 10.24 & 43.54 \\
\hline 25 & 50 & 25 & 0 & 1.08 & 1.08 & $12.31^{*}$ & $12.88^{*}$ & 13.95 & 42.62 \\
\hline 25 & 50 & 0 & 25 & 0.74 & 0.80 & 9.18 & 10.49 & 11.29 & 42.12 \\
\hline 25 & 25 & 25 & 25 & 0.95 & 0.95 & 5.70 & 6.23 & 7.19 & 39.79 \\
\hline \multicolumn{4}{|c|}{ Gupta's $(P \leq 0.05)$} & NS & NS & $*$ & $*$ & NS & NS \\
\hline
\end{tabular}

Industry standard: $75 \%$ peat $+25 \%$ vermiculite.

*Means expected to be among the best $(P \leq 0.05)$ as determined by Gupta's test.

${ }^{\mathrm{N}}$ Nonsignificant.

miculite transplants. In winter conditions, use of up to $25 \%$ coir did not compromise transplant growth visually.

Coir showed promise as an alternative medium to peat in transplant production. Florida transplant growers approved of transplants produced in $100 \%$ coir medium and all combinations of coir plus peat. Growers did not like transplants from media blended solely with coir and inorganic materials at any percentage. Reduced plant growth after 6 weeks in high-content $(>50 \%)$ coir blends was thought to be explained by microbial $\mathrm{N}$ immobilization, so further research should focus on whether transplant growth (and possible yields) could be increased by fertilizer and irrigation modification. In addition, the relationship between traditional attributes of transplant growth (i.e., stem diameter, root dry weight, etc.), visual quality, and fruit yield should be investigated further.

\section{Literature Cited}

Abad, M., M.D. Martinez-Herrero, P.F. Martinez Garcia, and J. Martinez Corts. 1992. Evaluacion agronomica de los sustratos de cultivo (Agricultural evaluation of crop media). I Jornadas de sustratos. Actas de Horticultura 11:141-154. SECH.

Arenas, M. 1999. Coconut (Cocus nucifera) pith or coir as an alternative media for tomato trans-
Handreck, K.A. 1992. Rapid assessment of the rate of nitrogen immobilization in inorganic components of potting media: I. Method development. Commun. Soil. Sci. Plant. Anal. 23:201-215.

Handreck, K.A. 1993. Properties of coir dust and its use in the formulation of soilless potting media. Commun. Soil. Sci. Plant. Anal. 24:349-363.

Hanlon, E.A., J.S. Gonzalez, and J.M. Bartos. 1996. IFAS extension soil testing laboratory (ESTL) and analytical research laboratory (ARL) chemical procedures and training manual. Circ. 812 . Univ. of Florida, Gainesville.

Hochmuth, G. and D.N. Maynard. 1998. Vegetable production guide for Florida. SP 170. Univ. of Florida, Gainesville.

Lemaire, F. 1997. The problem of the biostability in organic substrates. Acta Hort. 450:63-69.

Martinez, F.X. 1992. Propuesta de metodologia para la determinacion de las propiedades fisicas de los sustratos [Proposed method to determine substrate physical properties]. Actas del III Congreso de la SECH 55:66.

Martinez, F.X., N. Sepo, and J. Valero. 1997. Physi$\mathrm{cal}$ and physicochemical properties of peat-coir mixes and the effects of clay-material addition. Acta Hort. 450:31-46.

Meerow, A.W. 1994. Growth of two subtropical ornamentals using coir as a peat substitute. HortScience 29:1484-1486.

Pill, W.G. and K.T. Ridley. 1998. Growth of tomato and coreopsis in response to coir dust in soilless media. HortTechnology 8:401-406. 1999. LD1780 1999.A681.

Bragg, N.C., J.A.R. Walker, E. Stentiford, and M. Tantini. 1993. The use of composted refuse and sewage as medium additives for container grown plants. Acta Hort. 342:155-165.

Bragg, N.C. and G.M. Whiteley. 1995. Nitrogen draw-down index (NDI) test used with various peat alternatives in relation to plant growth observations. Acta Hort. 401:309-317.

Cantliffe, D.J. 1998. Seed germination for transplants. HortTechnology 8:499-503.

Cornell, J.A. 1990. Experiments with mixtures. Designs, models, and the analysis of mixture data (2nd ed.). Wiley, New York.

Cresswell, G. C. 1992. Coir dust-A viable alternative to peat? Biol. Chem. Inst., Rydalmere, Australia.

De Boodt, M. and O. Verdonck. 1972. The physical properties of the substrates in horticulture. Acta Hort. 26:37-44.

Evans, M.R. and R.H. Stamps. 1996. Growth of bedding plants in sphagnum peat and coir dustbased substrates. J. Environ. Hort. 14:187-190.

Evans, M.R., S. Konduru, and R.H. Stamps.1996. Source variation in physical and chemical properties of coconut coir dust. HortScience 31:965967.

Gerson, R. and S. Honma. 1978. Emergence response of pepper at low soil temperature. Euphytica 27:151-156

Gupta, S.S and M. Sobel. 1957. On a statistic which arises in selection and ranking problems. Ann. Math. Stat. 28:957-967.

Prasad, M. 1997a. Physical, chemical and microbiological properties of coir (cocopeat). Acta Hort. 450:21-27.

Prasad, M. 1997b. Nitrogen fixation of various material from a number of European countries by three nitrogen fixation tests. Acta Hort. 450:353-362.

Savithri, P. and K.H.Hameed, 1994. Characteristics of coconut coir peat and its utilization in agriculture. J. Plant Crops 22:1-18.

Styer, R.C. and D.S. Koranski. 1997. Plug and transplant production. A grower's guide. Ball Publ. Co., Batavia, Ill.

U.S. Dept. of Agriculture. 1998. Economics and statistics system (on-line). Internet address: http:// mann77.mannlib.cornell.edu/usda/

Vavrina, C.S. 1996. Summer plant house soil temperature and jalapeno germination. Citrus Veg. Mag. 60(6):49-50.

Vavrina, C.S., G.J. Hochmuth, J.A. Cornell, and S.M. Olson. 1998. Nitrogen fertilization of Florida-grown tomato transplants: Seasonal variation in greenhouse and field performance. HortScience 33:251-254.

Wever, G. and A.A. van Leeuwen. 1994. Measuring mechanical properties of growing media and the influence of cucumber cultivation on these properties. Acta Hort. 401:27-34.

Zimet, D. and C.S. Vavrina. 1995. Florida vegetable seedlings; concept, budget and cashflow. Florida Coop. Ext. Serv. Circ. 304. Univ. of Florida, Gainesville. 